\title{
Research on the Training of Innovative Talents in Applied Colleges and Universities
}

\author{
Jianbo Zheng \\ Binzhou University, Binzhou, 256600, China \\ E-mail: zjb2006@163.com
}

Keywords: Teaching reform; innovative talents; teaching methods

Abstract: Cultivating innovative talents is the main goal of teaching in colleges and universities. The teaching reform plays a great role in promoting the cultivation of innovative talents. The direction and theory of teaching reform are systematically expounded and analyzed. The reform of teaching mode and teaching methods should be optimized for cultivating innovative talents in modern construction.

\section{Introduction}

The development of society needs innovative talents, and the teaching of higher education needs to be reformed. The higher education in China has entered the stage of mass education from the elite stage. Due to the rapid development of higher education in China, the traditional concepts, teaching methods, teaching modes and educational quality evaluation mechanisms of higher education are far from national training of innovative talents and the requirement of building an innovative country. The higher education in China must carry out reform, cultivate more innovative talents, and actively provide intellectual support for the construction of an innovative country.

\section{The Importance of Teaching Reform}

The fundamental task of universities is to cultivate all-round development of socialist builders and successors. The completion of this task will be the fundamental criterion for measuring and testing the overall level of the University. Teaching is the core work of colleges and universities. Teaching reform is the core of the reform of colleges and universities [1]. Improving teaching quality is directly related to the quality of talents and the future of our motherland. It should arouse the attention of the whole society.

Since the third Plenary Session of the 11th CPC Central Committee, the higher education in China has made great progress and has made gratifying achievements. Many valuable experiences have been gained in terms of specialty setting and social needs, theoretical teaching and practical teaching, curriculum construction and teaching staff construction. It has made a useful attempt to break the single mode of talent training and participate in education by all sectors of society. However, under the impact of the tide of the market economy, the problem of the decline in the quality of teaching is common in Colleges and universities, which has aroused widespread concern [2]. 
In order to adapt to the requirements of the socialist market economy, higher education must face the society and deepen the reform. The teaching work is the central work of the University, which plays an important role in the quality of talent training and the level and benefit of the school. Therefore, attaching importance to the teaching work and deepening the teaching reform are the eternal themes of the reform and development of colleges and universities [3].

\section{The Main Problems of Higher Education}

\subsection{The prominent diploma education}

There are two manifestations of educational goal: first, the goal of the educated is only for the diploma, and the educator caters to the educator. At present, the degree of Diploma in higher education has declined, and the concern of the diploma corruption is the epitome of the educational background. Second, the educators cannot provide students with professional ability and comprehensive quality training conditions, education and access to education through the passive acceptance of how to test the reality, students in the examination oriented education in quality is only the spillover effect of examination oriented education, objectives and means of education appeared to have the order reversed [4].

\subsection{The common concept of examination oriented education}

First of all, the concept of exam oriented education is shown in the teaching management of colleges and universities. At present, China's universities in the evaluation of the quantity and quality of teachers, is still in the traditional class hours and the organizational structure of the classroom and students' test scores as the standard, the evaluation on students' learning effects are still based on the traditional examination, in the exam oriented education system, establish the teaching management method has not been improved. Secondly, the concept of exam oriented education is shown in the teaching activities of teachers. There is still a popular teaching method in university is a textbook, a lecture, this is a kind of What I say goes., simple knowledge type teaching mode, teacher motivation only means student learning is the examination, and finally the teaching effect of testing can only concentrate on the 2 hour exam. Third, the exam oriented education is shown in the students' learning activities. At present, the "pass theory" and "the theory of learning useless" are the typical reflection of the exam oriented education concept in the students. Because examination has become the decisive factor of students' fate, that is, whether they can get diplomas and whether they have good test records, resulting in a distinct stage of teaching process and lack of sustainable development. Teaching objectives have distinct knowledge and lack of social service [5].

\subsection{The neglected main position of students}

College students are the main body of work and service, but the dominant position of the students did not receive due attention, mainly in the following two aspects: one is the teaching management in Colleges and universities lack the consciousness of serving student, teaching reform no foothold on how to make students get the maximum income in higher education, and teaching management and coordination of departmental interests is still a major problem in teaching reform. The two is in the teaching process, not to change the traditional teaching mode, the correct understanding of the dominant position of students in teaching activities, in the process of the reform of teaching methods, the students' teaching concept is simply understood as to make their own learning, lack of innovation in teaching methods, teaching contents and teaching methods in the teaching process cannot create, students' autonomous learning, dynamic environment and autonomous guidance and control of the learning process of students, which will be a high level of 
high quality, creative and teaching ideas into a more simple teaching method [6].

\subsection{The lack of evaluation criteria for quality increment}

In modern higher education, the problem is quite prominent, and its root lies in a one-sided understanding of universal education [7]. According to the requirements of quality education, the responsibility of teachers not only impart knowledge out, more important is how to fully tap the potential of students, that is to say on the teaching and learning quality evaluation not only the evaluation of the stock of knowledge, also need to consider the evaluation of students' quality increment, this should also be the fundamental the level of quality education evaluation scale, only use this evaluation scale, in order to correctly evaluate the differences caused by differences in the quality of students objectively the learning effect and ability attribution, so as to establish the evaluation of teaching quality is foundation and quality of students development comparable basis [8]. As a matter of fact, due to the difficulty of evaluation of quality increment, few universities focus on the research and exploration work in this field. Therefore, establishing a scientific evaluation system of teaching quality in universities is always a difficult problem that puzzles the teaching reform in Colleges and universities.

\section{The Thinking and Direction of Teaching Reform}

At present, the teaching process of universities in China does not really get rid of the influence of the traditional education model. This century will be a more quality - oriented century. The shift from quantity to quality marks the end of an era and the beginning of another. The importance of quality is the proposition of an era. Who despises quality will pay a heavy price for it [9].

The reform of classroom teaching is the front of college teaching reform, and the whole process of teaching reform must be the development and perfection of quality education and practical teaching. The reform of quality education for college students should be carried out in the management of students to achieve the purpose of educating and educating people. Taking the structure of Teacher centered teaching process, which is governed by our schools at all levels for many years, for example, its characteristics are that teachers transmit or instill teaching contents to students through teaching, blackboard writing and teaching media. Under such a structure, teachers are active teachers, students are passive external stimuli receivers, instilling objects, media is a tool to assist teachers to inculcate students, and textbooks are the contents of instillation, and the only source of knowledge for students. If our education is not seriously reformed, the students that have been trained will generally lack innovative thinking and innovative ability, and it is difficult to undertake the task of revitalizing the Chinese nation [10].

\subsection{Teaching reform is an ideological revolution, and formalism cannot be made.}

Teaching reform is a revolution in teaching thought. We must stick to the way of seeking truth and pragmatism. We should combine ideas with reality scientifically based on changing educational ideas and educational concepts. Ideologically, the reform of teaching must adhere to the Scientific Outlook on Development. The content of Scientific Outlook on Development is: "adhere to the people-oriented, set up a comprehensive, coordinated and sustainable development concept, and promote the overall development of economic society and people". As a general policy of China's development, Scientific Outlook on Development has rich and profound connotations [11]. It has established a new guiding ideology for the social development of our country at the present stage, and has also pointed out a new goal and direction for the development of education.

It is necessary to update the old concept of teaching, especially the scientific knowledge attitude of general education and professional education in Colleges and universities. Professional education is the depth of university education. It marks the amount of professional knowledge in a subject 
area. General education is the breadth of university education, and pays more attention to the differentiation between disciplines and professions. The successful experience tells you that the cultivation of innovative talents in the field of professional education can be broken through with the help of the inspiration of general education [12].

\subsection{Teacher-oriented, renewing ideas}

University education is the beginning of the study of professional knowledge.

As professor Zhang Jianping of Zhejiang University has said, undergraduate education is self-learning Book stage. Postgraduate education is self-reading stage. Doctoral education is self-seeking stage. Of course, in terms of the education of the present and specialized stages, the primary knowledge system of discipline is formed, which is the depth and extent of the training of talents. At this level, the cultivation of innovative talents requires teachers to change the traditional "indoctrination" or "cramming" for the "discussion", "research", "problems" approach, to strengthen practice teaching, improve students' autonomous learning ability, teachers' teaching focus on discovery learning method, perspective the principle of thinking and problem solving ability. The change of teaching methods means the orientation of the teacher's leading role and the formation of the main role of the students [13].

We should encourage teachers to carry out the study of education law. Facing the challenge of new technology, teachers must constantly enhance their scientific research ability and realize the transformation from experienced teachers to scientific research teachers. In the development of academic atmosphere, advocate and form a good atmosphere of advocating science and innovation, stimulate the creative passion of teaching and research staff, good academic atmosphere, encourage the creation of excellent achievements, strengthening academic exchanges and cooperation, and constantly improve the academic level of teachers; strengthen exchanges with advanced educational technology, learn from the excellent teachers colleges outside or abroad learning does not rest on its laurels, create a good atmosphere of academic exchanges [14].

The important role of the teacher in the teaching reform cannot be questioned, teachers are not only teaching preacher role in teaching activities is a guide, researchers, designers and collaborators.

With the deepening of educational reform, teachers' occupational stress and psychological pressure will increase, which will cause the job burnout of teachers to become more and more serious. Some schools carry out the "supervision system of teachers" for the examination of classroom teaching, the evaluation of teachers' teaching and the activities of students' evaluation and teaching. These measures promoted teachers' awareness of improving their quality, but also increased teachers' sense of urgency and sense of crisis, which led to teachers' dissatisfaction with the status quo. If it's going to happen, it will threaten teachers' physical and mental health. As a "by-product" in such a reform, the negative impact of job burnout cannot be ignored. In the teaching reform, in addition to the appropriate incentives and pressure, we should take measures to effectively dredge the negative emotions in the teaching reform, and effectively promote the continuous progress of the teaching reform [15].

\subsection{Innovative teaching methods}

Teaching reform should not blindly pursue the renewal of teaching forms. Introducing multimedia technology into classroom can really arouse students' vision, hearing and imagination, but the problem is that courseware is not good at all.

The use of modern information technology is indispensable in the reform of higher education. First, it is necessary for university teachers to use multimedia courseware in the classroom as far as possible. Through the courseware, the abstract problems can be specific and the complicated 
problems are simplified. The most important thing is that it can expand and increase the amount of knowledge information in college students' classroom teaching, so it is necessary to give full use of multimedia teaching. The two is to use the information technology education to extend the classroom knowledge education. The construction of excellent open class can teach students how to make use of open class, especially the open class resources of world-famous universities, which is of far-reaching significance for improving the quality of education in newly built applied undergraduate schools, and is worth learning from. Most of the teaching courseware are PPT presentation, and the professional level of the courseware should be improved. Some schools have affected the teaching effect because the supporting facilities of the multimedia classrooms are not sound enough. And because of differences between the various courses of Arts, different teaching content, so that some courses cannot use multimedia teaching, such as advanced mathematics, linear algebra formula, more focus on the problem steps course only multimedia presentation was not enough to enable students to fully grasp. Therefore, the school should encourage teachers to make excellent multimedia teaching courseware, but not blindly rely on CAI courseware. In order to carry forward the advantages of traditional teaching, the advantages of traditional educational means are not abandoned while the modern means of education are effectively used [16].

\subsection{Scientific selection of teaching materials}

The textbook is not only a tool book for teachers, but also a reference book for students to learn from themselves. The advantages of self-evident: revision, less errors, influence, authority. This kind of teaching material general system science, let the beginner less take the curve, easy to start. The purpose of optimizing the textbook is to create a good learning condition for the students [17].

The teaching reform of the course, but not with vigor and vitality as a mere formality, "individualized, and tailored" embodies the concept in different background. The curriculum teaching reform involves not only the teachers but also the corresponding students, the teaching managers and the allocation system of teaching management resources. The course teaching should take the road of reform, and adhere to the road of "simple, easy, effective, efficient and sustainable". With the idea of innovation, the teaching reform is actively carried out in order to make the innovation education receive the actual effect [18].

\section{Conclusion}

With the continuous change of the demand for innovative talents in the development of social economy and science and technology in China, it is imperative to reform the training mode of talents in universities. In recent years, many colleges and universities continue to reform the traditional talent training mode, and have explored more effectively in the aspects of student personality training, cross compound talents training, practice teaching reform, and building innovative talents training system. The key question now is to follow the law of education and the growth of talent at the same time, to further establish the concept of innovation education, and by improving the personnel training programs, scientific personnel training objectives, through the promotion of teaching and scientific research closely approach, actively promote the innovation of personnel training.

\section{Acknowledgements}

This research was funded by key Project of Experimental Technology of Binzhou University. Item number: BZXYSYXM201705. 


\section{References}

[1] Ma Tingqi, Shi Jiacui. The training of innovative talents and the reform of university talents training mode [J]. Modern Education Science, 2011(05):104-107.

[2] Zhang Feng. Analysis and Countermeasures of practical teaching in local science and Engineering Universities [D]. Hebei University of Science and Technology, 2012.

[3] Zhang Hong. Research on practical teaching reform based on the training of Applied Innovative Talents [J]. Modern Educational Technology, 2015(10):119-125.

[4] Zhao Yizhi, Hang Yu. The teaching reform of adult education under the network learning model [J]. China Adult Education, 2017(22):100-102.

[5] Ye Jing, Chen Feng. Research on the theoretical foundation of the construction of the overturned classroom teaching model in Colleges and Universities [J]. The Guide of Science \& Education, 2017(11):21-22.

[6] Qi Weiwei. Reflection on the teaching reform of scientific disputes [J]. Contemporary Education Research and Teaching Practice, 2017(04):6.

[7] Huang Yue, Han Xibin, Cheng Jiangang. Deviation analysis of the stage characteristics and implementation effect of the mixed teaching reform [J]. Modern Distance Education Research, 2017(05):69-77.

[8] Xie Heping. Taking innovation and entrepreneurship education as the guide to deepen the reform of education and teaching [J]. China Higher Education Research, 2017(03):1-5.

[9] Li Zhiyi. Adapting to the requirements of certification and promoting the reform of engineering education and teaching [J]. China University Teaching, 2014(06):9-16.

[10] Gu Xiaorui. Research on the training mode of innovative talents under the background of comprehensive reform of colleges and Universities [D]. Qiingdao University, 2017.

[11] Song Chunyan. The path of teaching reform based on core literacy [J]. Education Modernization 2017(35):44-45.

[12] Li Na, Jia Fang, Yang Hanyu, Zhao Zhuo. The difficulties and Countermeasures of the reform of practical teaching in China's colleges and Universities [J]. University Education, 2015(01):16-19.

[13] Xu Dehong. Research on the influencing factors of promoting mixed teaching reform in undergraduate colleges and Universities-case study based on Fuzhou University [J]. China Educational Technology, 2016(12):141-145.

[14] Hou Yuying. Research on the problems and Countermeasures in the course of curriculum Reform-Taking the classroom teaching reform of three schools as an example [D]. Nanjing Normal University, 2017.

[15] Zhang Shilei, Meng Xiyuan. Experimental teaching reform and exploration of creative and practical talents training [J]. Experiment Science and Technology, 2014(01):149-152.

[16] Zhong Yongwei. A probe into the methodology of university teaching reform [J]. Journal of National Academy of Education Administration, 2012(01):43-47.

[17] Pei Tina. The outline of educational innovation and the reform of school classroom teaching [J]. Curriculum, Teaching Material and Method, 2012(02):3-9.

[18] Tang Junya. The trend of the reform and construction of the first class undergraduate teaching in China [J]. China Higher Education Research, 2016(07):1-6. 